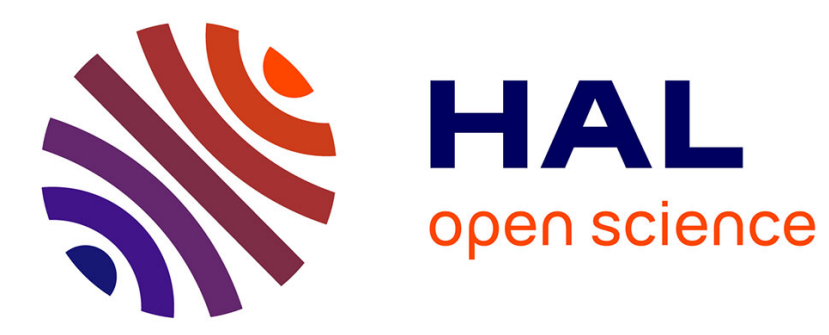

\title{
Two Decades of French Urban Policy: From Social Development of Neighbourhoods to the Republican Penal State
}

Mustafa Dikeç

\section{- To cite this version:}

Mustafa Dikeç. Two Decades of French Urban Policy: From Social Development of Neighbourhoods to the Republican Penal State. Antipode, 2006, 10.1111/j.0066-4812.2006.00565.x . hal-01274378

\section{HAL Id: hal-01274378 \\ https://hal-enpc.archives-ouvertes.fr/hal-01274378}

Submitted on 15 Feb 2016

HAL is a multi-disciplinary open access archive for the deposit and dissemination of scientific research documents, whether they are published or not. The documents may come from teaching and research institutions in France or abroad, or from public or private research centers.
L'archive ouverte pluridisciplinaire $\mathbf{H A L}$, est destinée au dépôt et à la diffusion de documents scientifiques de niveau recherche, publiés ou non, émanant des établissements d'enseignement et de recherche français ou étrangers, des laboratoires publics ou privés. 


\title{
Two Decades of French Urban Policy: From Social Development of Neighbourhoods to the Republican Penal State
}

\author{
Mustafa Dikeç \\ Faculty of Social Sciences, The Open University, Milton Keynes, UK; \\ m.dikec@open.ac.uk
}

This paper provides an overview of French national urban policy for the period 1981-2002, organized around three themes: spatial conceptualizations of intervention areas and changing scales of intervention, discursive articulations of intervention areas, and legitimation of state intervention. By relating the transformations of this policy to the contemporary restructuring of the French state, the paper argues that although there are elements of convergence, the contemporary restructuring of the French state differs remarkably from a US or UK-style neoliberalization, partly because of the republican tradition emphasizing the active role of the state for the well-being of its citizens. This restructuring carries the signs of the strong state tradition in France, and is best understood as an articulation of neoliberalism with established political traditions, an articulation that I try to capture with the notion of a "republican penal state".

\section{Introduction}

One of the key elements of the burgeoning geographical literature on neoliberalism is its emphasis on the production of new spaces and regulatory frameworks at various scales in interpreting contemporary transformations of cities and states. Such an emphasis encourages an interpretation of neoliberalism not as something merely happening to cities and states, but rather as a specific form of political rationality producing new spaces, and at the same time produced upon and through the spaces of particular states and cities. An important implication of such an interpretation is that it allows for variation: if neoliberalism is itself produced upon and through diverse geopolitical spaces (and is also producing them), then there should be hybrid forms of neoliberalism (Larner 2003; Peck 2004). Yet such variations have not figured in the accounts of neoliberalism and neoliberalization in geographical literature, which are mainly inspired by US, UK, and, to some extent, Canadian cities and states. Although the perils of reproducing one hegemonic story of neoliberalism are recognized and the hybrid nature of neoliberalism emphasized, little or no empirical evidence is provided. 
This paper offers one example in that direction by providing a review of French urban policy during the 1981-2002 period, and relating the transformations of this policy to the contemporary restructuring of the French state along increasingly authoritarian lines. That this restructuring involves a commitment to some form of neoliberalism has been observed by many scholars (Jobert and Théret 1994; Levy 2001, 2002; Schmidt 2002; Wacquant 2001). However, this restructuring also carries the signs of the strong state tradition in France, influenced by a certain idea of the "republican state" and its social obligations towards its citizens. In this paper, I argue that established political traditions affect forms of neoliberalization and state restructuring, and suggest that such restructurings are best understood as articulations of "the neoliberal project" with established political traditions, an articulation that I try to capture, for the case of France, with the notion of a "republican penal state". While there are linkages and echoes that suggest that the French path is converging with a neoliberal one, there exist major tensions and contradictions deriving from inherited political traditions-of which an emphasis on "the republic" and its duties is one. The notion is also aimed at taking into consideration variations in what Wacquant has identified as the "European penal state", which follows the strong state tradition in Europe, and intensifies regulation through both social and penal policy-making. The "left hand" of the state is still active, but it is increasingly accompanied by its "right hand" with intensified use of the police, courts and prison system, and with a form of regulation following a "panoptic logic" that involves the criminalization of the poor and the close surveillance of populations seen to be problematic (Wacquant 2001).

The European penal state, however, varies with different political traditions, deploying different containment strategies and legitimizing discourses. The "new penal commonsense" (Peck 2003) came to France with a republican twist, and shifted emphasis from prevention to repression through a legitimizing discourse organized around "the republic" under threat by allegedly incompatible cultural differences and the formation of "communities" unacceptable under the "one and indivisible" republic. The republican penal state still has an active "left hand", which, however, is increasingly accompanied by its "right hand", concerning, in particular, the deprived neighbourhoods in the peripheral areas (banlieues) of large cities-most of which are former working-class neighbourhoods, marked, since the 1980s, by constantly increasing unemployment rates. This is not to imply that the French state, after a decade of absence, is now "back" in deprived areas, as in the "roll-out neoliberalism" of the US and UK cases (Peck and Tickell 2002). The French state has been present in deprived areas through its urban policy (among others) for years-the 1980s 
included. The change between the 1980s and the 1990s, in this sense, is not so much the return of the absent state to spaces of poverty and mass unemployment as the remarkable change in the modes of intervention and discursive articulations of such spaces. It is this change that I try to chart in this paper through an overview of a national urban policy conceived to address the problems of deprived neighbourhoods in the banlieues. The overview is organized around three themes: spatial conceptualizations of intervention areas and changing scales of intervention, discursive articulations of intervention areas, and legitimation of state intervention. The first one of these considers to what degree the national policy programme has sought to encourage and institutionalize a competitive logic through its constitution of spaces of intervention. The second one relates the discursive articulations of intervention areas to the rise of an exclusionary form of republicanism with nationalist overtones-to which I refer to as "republican nationalism"-in the 1990s. This aspect is crucial in understanding the transformations of urban policy in France, which is tightly linked to debates around immigration and the presence of ethnic communities, usually associated with the banlieues and their construction as problem. The third theme illustrates the consolidation of the penal state upon and through urban policy's spaces of intervention, particularly those located in the banlieues. Before moving on to French urban policy, however, I first provide working definitions of neoliberalism and neoliberalization in the section below. This is followed by a section on the tensions and contradictions between neoliberalism and the republican tradition.

\section{Neoliberalism, Neoliberalization and the City}

"Despite the familiarity of the term, defining neoliberalism is no straightforward task", write McCarthy and Prudham (2004:276). This is so, they argue, partly because the term refers to a variety of principles and practices, too complex to be effectively captured by a single definition. There is also concern about the homogenization of specific forms of neoliberalism under overarching definitions (Larner 2003; Peck 2004). Defining neoliberalism, then, is neither an easy task nor a particularly desirable endeavour. However, any attempt at relating forms of restructuring to neoliberalism in order to see to what extent-if any-they can be seen as part of a larger "neoliberalization" process requires at least a tentative working definition.

There are, nevertheless, some general definitions of neoliberalism. Larner, for example, takes neoliberalism to signify "new forms of political-economic governance premised on the extension of market relationships" (2000:5). For Thrift, "neoliberalism is a set of conventions or stories about the right ways to do things in order to succeed 
economically_as a firm, a country, a person or ... a city" (1999:276). This set of conventions is premised on the extension of market relationships, driven by the logic of competition and effectiveness. In its most commonly conceptualized form, neoliberalism indicates a shift from the welfare state to the logic of the market. Political governments focus more on economic efficiency and competitiveness, and less on, say, full employment and social welfare. Thus, the market, instead of the caring institutions of the (welfare) state, becomes the source of social well-being. This conceptualization of neoliberalism as a "policy framework" (Larner 2000) implies a "roll back" of welfare state activities, and is usually concretized by policies of liberalization, privatization, and deregulation.

But both Larner's and Thrift's definitions are aimed at capturing something more than mere policy frameworks. Neoliberalism is more than a set of economic policies: it is a new form of "political-economic governance" (Larner 2000:5); "one particular way in which government is made possible" (Thrift 1999:276); a "political rationality that both organizes these policies and reaches beyond the market" (Brown 2003:4). This is what Larner (2000) calls "neoliberalism as governmentality" - a particular form of governance that constitutes individuals and institutions in compliance with the norms of the market, producing calculating, individualized subjects responsible for their own well-being (or misery, for that matter), calculated, profitable economic and social policies aimed at encouraging-even requiring-competition, and institutions guided by the overriding objectives of competitiveness and efficiency. As Brown maintains:

neo-liberalism is not simply a set of economic policies; it is not only about facilitating free trade, maximizing corporate profits, and challenging welfarism. Rather, neo-liberalism carries a social analysis which, when deployed as a form of governmentality, reaches from the soul of the citizen-subject to education policy to practices of empire. Neo-liberal rationality, while foregrounding the market, is not only or even primarily focused on the economy; rather it involves extending and disseminating market values to all institutions and social action, even as the market itself remains a distinctive player. (Brown 2003:7)

In this paper, I take "neoliberalism" as a political rationality, and define "neoliberalization" as a particular form of restructuring guided by this political rationality premised on the extension of market relations that privilege competition, efficiency, and economic success. Such a definition seems to me useful for three reasons. First, it emphasizes a process rather than a static condition. Second, it encourages an approach that does not reduce neoliberalism to the application of a set of economic policies. Third, it pays attention to 
practices that (re-)constitute spaces, states, subjects, individuals, and institutions for the purposes of government in a particular way. It takes into consideration not only the various techniques and devices of government, but also the constitution of the objects and subjects to be governed. Thus, for the case of French urban policy, I focus on the constitution of its spaces of intervention, their articulation with different kinds of issues and problems, and changing forms of intervention and their legitimization during the two decades of this policy. I see this policy as part of a larger restructuring of the French state that involves new forms of statecraft and governmental practices, re-scaling of the state apparatus, and the production of new spaces - of regulation, intervention, and containment (Larner 2003; Peck 2001, 2003).

As for the manifestations of neoliberalism at the urban level, three features are commonly cited in the literature as characteristic of urban neoliberalism, which could be seen to reflect economic, social, and penal aspects of it. The first issue is the institutionalization of interurban and interregional competition through (neoliberal) urban policies based on the logic of the market. This is fostered through a variety of programmes that include place-marketing, enterprise zones, urban development corporations and public-private partnerships (Brenner and Theodore 2002; Peck and Tickell 2002; see also Jones and Ward 2002 for a political economy, and Raco and Imrie 2000 for a governmentality approach to British urban policy). The second issue relates to the socioeconomic and sociospatial manifestations of neoliberalism. Neoliberal strategies deployed in cities, it has been argued, sharpen socioeconomic inequalities and displace certain groups from cities, whose presence in the city is deemed undesirable. (Hubbard 2004; MacLeod 2002). Urban neoliberalism is deeply concerned with imposing a certain "social landscape" on the city. The third issue follows from the second, and involves new and aggressive strategies of policing and surveillance aimed at particular groups and particular spaces (mostly city centres), criminalization of poverty, and the increased use of the penal system (Peck 2003; Wacquant 2001).

But the question remains as to what it is that makes these orientations specifically "neoliberal". Economic strategies of the sort described above have already been effectively discussed under "urban entrepreneurialism". A concern with certain groups in the city and its public spaces is not distinctively neoliberal, nor is it a new occupation of urban governments. And, one could be authoritarian without being neoliberal; authoritarian forms of urban governance do not necessarily follow from neoliberalism. In short, all of these commonly cited features of urban neoliberalism, when considered separately, could occur in political regimes that are not necessarily 
committed to neoliberalism. This brings me to another feature of neoliberalism, a feature that accounts for my focus on the state and its construction of urban policy. What makes such orientations neoliberal, I believe, is the political rationality underlying them (premised on the extension of market values), and the active construction-and not only laissez faire - of the conditions in which such a political rationality can be disseminated, including markets, but also various institutional structures and practices that privilege competition, efficiency, and economic success. Neoliberalism requires "political intervention and orchestration" (Brown 2003:10) - through political institutions, law, policy, institutional practices and social norms-in order to encourage and facilitate competition, efficiency and rational economic behaviour on the part of the individual members and institutions of the society (Brown 2003; see also Peck and Tickell 2002:395-396). Neoliberalism extends as a political rationality, and not merely as a policy package, which requires political agendas that construct the conditions of its development, dissemination, and eventually normalization. For example, Peck and Tickell (2002:394) argue that the development and deployment of the political rationality of neoliberalism was crucial in reinforcing, extending, and, more importantly perhaps, normalizing the consolidation of competitive urban regimes-either to "win" in the interurban competition, or to secure a place in the global race. And when neoliberal rationality extends to the state, not only the state responds to the needs of the market (through measures that range from monetary policy to immigration policy, from welfare programmes to the workings of the penal system), but also the criteria for its success and legitimacy get indexed to the market. The state is successful as long as it secures and promotes the market, the health and growth of which is now its responsibility and the basis of its legitimacy (Brown 2003:12-14).

The orientations referred to above may come together around this political rationality rather nicely, consolidating a relatively coherent neoliberal regime - as, for example, in certain US cities-or, in other cases, while the political rationality of neoliberalism guides mainly economic policies, policies in other spheres follow other rationalities, producing hybrid and sometimes contradictory forms of neoliberalism-as, for example, in France, to which I now turn.

\section{The Republican State and its Contradictions}

"Neoliberalism à la française", Jobert and Théret (1994:80) maintain, is "not a shameful neoliberalism. Its reconciliation with the Republic granted it a degree of authority and respectability". They refer to this reconciliation as "the republican consecration of neoliberalism". Whether shameful or not, it is nevertheless possible to distinguish 
a French version of neoliberalism deeply influenced by the republican tradition emphasizing the social obligations of the "republican state" towards its citizens. This is a conception of the state that is highly endorsed by the public as well, which perhaps was best exemplified by the massive strikes in 1995 against the then Prime Minister Alain Juppé's attacks on the welfare state.

The republican tradition is based on the presupposition that "without a common culture and a sense of common identity, the political as well as physical integrity of France would be "threatened" (Jennings 2000:586). The French citizen is a universal individual-citizen, directly linked to the nation-state, and national political membership requires the acceptance of French cultural values (Feldblum 1999; Safran 1990). It is universalistic and assimilationist, it combines political membership (citizenship) with cultural membership (assimilation into "French culture"), and emphasizes the role of the central state in actively promoting citizenship and securing "solidarity", "social bond" and "social cohesion" (Feldblum 1994; Silver 1993, 1994), mainly through an impartial technocratic bureaucracy. The republican tradition, therefore, refers to one particular way of conceptualizing the relations between state and society, with particular emphasis on the duties and obligations of the central state vis $\grave{a}$ vis its citizens. It follows a social not an economic rationality (see Silver 1994). Still influential in many ways, the French conception of the republican state involves the state's obligations "to guarantee citizens' social justice through the provision not just of traditional social services but also public infrastructural services" (Schmidt 2002:279). Such a conception not only prevented - to a certain extent, at least-social policy reforms along neoliberal lines, but also made it rather difficult to legitimize such modifications since the neoliberal political rationality and the political rationality underlying the "republican state" were logically contradictory. This contradiction continued since the 1980s with belt-tightening economic policies and expansive social policies and services (Schmidt 2002).

The Socialist government of the early 1980s had tried to implement the programme for which they were elected, which included increased state intervention and nationalization. Two years later, following the monetary crisis of 1983, already under pressure from financial markets and the EEC, the Socialist government started to move towards neoliberal economic policies, adopting policies of budgetary austerity and privatization. This orientation continued with the successive governments of the left and the right through policies of financial market liberalization, privatization, business deregulation, and labour market decentralization (Budgen 2002; Jobert and Théret 1994; Knapp and Wright 2001; Schmidt 2002). The application of such policies, however, carried the mark of France's (former) state 
capitalism. Despite market-oriented reforms in the last two decades, as Schmidt $(2002,2003)$ effectively argues, the French state has not moved towards market-capitalism, but from "state-led" capitalism to a sort of "state-enhanced" capitalism, where the state still plays an active, if diminished, role. Furthermore, while implementing policies associated with neoliberalism, the French state has not completely retreated from its welfare functions. Instead, it has intensified its social interventions through public aid policies, minimum income programmes, government-sponsored work contracts, and a universal health coverage plan (Levy 2001; Wacquant 2001). Increasingly since the 1990s, social policy has become a key issue for governments of both the left and the right (Levy 2001).

The French state's "neoliberalism", then, calls for reservations. Indeed, given the strong state tradition in France, neoliberalism as a political ideology has little or no place-at least to be voiced explicitly-even in the French right's political agenda. It should be remembered that before the dismantling of the dirigiste state in the 1980s, it was the French right that ran the dirigiste model for decades, and that the main party of the right (the Gaullist RPR) was founded on statist principles (Levy 2002). As a political ideology, neoliberalism briefly entered the right's agenda only after they lost power to the left in the early 1980s as a counter-ideology (Schmidt 2002), and during Chirac's unsuccessful 1986-1988 government. Even then, Chirac had promised not to touch the welfare state. And during his 1995 presidential campaign, Chirac - the head of the main party of the right, RPR — had denounced his fellow party member Balladur's (then Prime minister) neoliberalism, and organized his campaign around the theme of "social fracture", which he would seek to heal through intensified state intervention. Before he reversed course a few months later with a stated aim to qualify for European Monetary Union by reducing the country's budget deficit, concrete measures indeed were taken, such as a $4 \%$ increase in minimum wage, and financial subsidies to employers willing to hire unemployed youths (Levy 2001).

The republican tradition, therefore, is not without influence on the contemporary restructurings of the French state, which differs remarkably from a US or UK-style neoliberalization. Three issues, however, should be emphasized here. The first one relates to the emphasis on French cultural values, which is directly linked to political membership in the "one and indivisible" republic. The republican tradition is "far more intolerant of diversity in public life than American pluralism" (Silver 1993:346), and is prone to taking exclusive tones following from its obsession with culture. Exemplary in this sense is the message delivered by Charles Pasqua shortly before taking office as the Minister of the Interior in the centre-right 
government of $1993 .{ }^{1}$ Pasqua stated that a "multi-ethnic and multiracial" society would be tolerable, but not a "multi-cultural" one. "If France does not suit them, all they have to do is go home and bugger off [foutre le camp] ... Those who want to live on the national territory must become French and assimilate our culture, we don't have to put up with the others" (Le Monde 21-22 March 1993:11). Such a tendency may easily lead to the demonization of "other" cultures as threats to national identity and cohesion, but also to the formulation of problems as following from cultural differences. This has partly been the case in the evolution of urban policy, and I will come to that below.

The second issue relates to the uses of republican rhetoric ("social cohesion", "solidarity", "social bond") in political discourse. Given the deep attachment to the republican tradition, such rhetoric is usually part of political agendas, in words if not always in deeds. It seems, indeed "the only way to win" even for right-wing governments, who may then shift to neoliberal agendas, as Chirac did in 1995 (Budgen 2002:32). But the reverse may also be true. The Socialist government of the early 1980s, for example, largely avoided the republican rhetoric (including "the Republic"), and employed, instead, notions such as "inequality" and "social justice", a strategy aimed at connecting issues to the structural dynamics of capitalism rather than to an organic conception of society (see Silver 1994). These notions, however, gradually disappeared from the political discourse after the 1983 turn of the government, and were replaced with the notion of "solidarity", which, it was argued, implied a tacit acceptance of persistent inequalities (Jobert and Théret 1994), and which could be seen "as much as a way of buying off the most affected interests [by neoliberal economic policies] as the defence of traditional values" (Schmidt 2002:277).

The third issue follows from the previous two, and is particularly important given the argument pursued in this paper: that although there are elements of convergence, the contemporary restructuring of the French state differs remarkably from a US or UK-style neoliberalization, partly because of the republican tradition emphasizing the active role of the state for the well-being of its citizens. Such an argument emphasizing the importance of established political traditions in the restructurings of states runs the risk of asserting a certain national exceptionalism, accounting for everything and nothing in particular. Therefore, I do not submit that the republican tradition has remained an historically continuous "model" with coherent policy implications. Far from being an unchanging model, even the very meaning of "republicanism" is constantly contested, and the term is employed by the extreme-right leader Le Pen as well as anti-racist organizations calling for a "true republicanism" (see Feldblum 1994). 
As I mentioned above, Socialists largely avoided the term in the early 1980s. Starting with the early 1990s, the republican conception acquired an exclusive form with an emphasis on French identity and cultural values. Since then, the language of republicanism continues under the right and left, both emphasizing the authority of the state. In none of these periods, however, have the social services of the state been dismantled, although there have been attempts to do so. For these reasons, it is best to see republicanism as a relatively established political tradition that emphasizes the social duties and obligations of the state for the well-being of its citizens, not as a "model" unanimously followed by succeeding governments. Such an approach also requires an attentiveness to various "republicanisms", and the reasons behind their (re-)appearance, such as the resurgence of republican nationalism in the 1990s, which affected urban policy as well.

\section{French Urban Policy}

In May 1981, Socialists came to power under the presidency of François Mitterrand with an ambitious programme that involved such politically fragile issues as the abolition of capital punishment, suspension of the expulsion of immigrants, voting rights for immigrants in local elections, decentralization, self-management (autogestion), and an economic programme that included more state intervention and nationalization. A bitter surprise, however, was awaiting them: the so-called "hot summer", which was marked by incidents of unrest in social housing neighbourhoods at the peripheral areas (banlieues) of large cities. By the end of the summer of 1981, some 250 cars were stolen and set on fire in social housing neighbourhoods at peripheral areas of Lyons, Marseilles, Roubaix, Nancy, and Paris (Jazouli 1992). The occurrence of such incidents in the summer of 1981 was particularly important. The left was in power for the first time in the Fifth Republic with an agenda including politically contentious issues. In this context, such incidents had a particular significance, especially for the opposition right, which had centred its critique on the "soft" attitude of the new government towards immigration (Bachmann and Le Guennec 1996; Mucchielli 2001). Furthermore, "race riots" - something unimaginable under the republic ${ }^{2}$ - had occurred on the other side of the Channel, and their ghost was haunting the French republic. French urban policy ('la politique de la ville') started in this particular context, which eventually led not only to the introduction of the banlieues in the agenda as a political issue, but also to their association with the issue of immigration. The focus of this urban policy program has been largely on the deprived neighbourhoods in the banlieues, where large numbers of immigrants live. ${ }^{3}$ Originally conceived as an experimental 
programme focusing on a few sites, it was later institutionalized, with an increase in the number of selected areas from an initial 16 to about 750 .

The main issues that French urban policy is concerned with, the very issues that stimulated its conception and, later, institutionalization, have not changed: incidents of social unrest, and the concentration of certain groups in certain areas, getting trapped in there because of economic difficulties generated mainly by massive job losses of the economic restructuring processes of the 1980s and 1990s. But the way this problem has been conceptualized and the representations of intervention areas have changed remarkably over the years. Below I illustrate some of the major changes through an account organized around three themes: spatial conceptualizations of intervention areas and changing scales of intervention, discursive articulations of intervention areas, and legitimation of state intervention.

The account is organized around these three themes since they help us understand the major transformations of French urban policy in the last two decades. Furthermore, an analysis organized around these themes illustrates different political rationalities guiding urban policy, and how they have affected the constitution of its spaces of intervention. The focus on space seems to me justified in such an analysis since urban policy conceives of its object spatially. As we will see, while there have been attempts to orient urban policy towards the extension of market relations, the main determinant factor, until now at least, has remained that of the republican tradition with its emphasis on the responsibility of the state to maintain "social cohesion" with increasingly authoritarian measures.

\section{From the Neighbourhood to the City-Region and Back Again} When urban policy was first conceived in the early 1980s, the aim was to create a new territorial dynamic through the "spatialization of social policies" (Chaline 1998). The first programme-Social Development of Neighbourhoods (Développement social des quartiers, DSQ hereafter) - started with this aim, and its spatial approach, at the time, was seen as innovative (as opposed to sectoral policies). Efforts would be concentrated on a few selected areas-the so-called "priority neighbourhoods"-as part of an experimental policy program. The geography of the priority neighbourhoods of urban policy, however, has gone through several changes since the DSQ, not merely in terms of the number of neighbourhoods to be included, but, more importantly, in terms of the spatial conceptualizations of intervention areas. Three different geographies of priority neighbourhoods can be 
discerned in the two decades of French urban policy: local, contractual, and statist (étatique).

The early years of urban policy were characterized by what we could call a "local geography" of priority neighbourhoods, which was established through local knowledge and specificities without "objective" and institutionalized criteria of selection (Estèbe 2001). What started as an experimental policy, however, quickly grew, and the number of neighbourhoods went up from an initial 16 to 148 a couple years later. The initial local geography of the priority neighbourhoods of urban policy turned into a "contractual geography" at the end of the decade, with the initiation in 1989 of the City Contracts (Contrats de Ville) program, which was part of the reforms of the Rocard government that was deeply committed to urban policy. These contracts defined a program of action between the state and the localities for a period of five years, with three major objectives. First, changing the scale of intervention from individual neighbourhoods to the entire city-region, which was indicated by the change from Social Development of Neighbourhoods (DSQ) to Urban Social Development (Développement social urbain, DSU). Related to this, the second objective was to encourage mayors to take into consideration broader social and economic issues. And finally, the programme hoped to foster inter-communal cooperation, by bringing communes together in devising projects to address deprived areas.

But the City Contracts programme encountered serious problems in implementation. It was argued that the proposed projects failed to take into consideration deprived areas, and that some localities used the contracts as an opportunity to finance projects that had little or nothing to do with the so-called "neighbourhoods in difficulty". Inter-communal cooperation, finally, was far behind expectations (Donzelot and Estèbe 1999; Le Galès and Mawson 1994; OECD 1998). Nevertheless, the City Contracts program was an attempt to take into consideration larger dynamics than merely focusing on neighbourhoods, and was also supported by many laws passed in the early 1990s. The Besson Law of 31 May 1990 defined the right to housing as a "duty of solidarity for the entire nation", and required the departments to financially contribute to "solidarity funds" at least as much as the state. Another law on "financial solidarity", the Loi de dotation de solidarité urbaine of 13 May 1991, was aimed at establishing inter-communal solidarity through a transfer of funds from richer communes with less social problems to poorer communes with more social problems. The most mediatized of the new laws was the Loi d'orientation pour la ville (LOV) of 13 July 1991, known also as the "anti-ghetto law". The concern of the LOV was basically social housing. It envisioned achieving "social mixity" by obliging agglomerations with more than 200,000 inhabitants to provide $20 \%$ social housing. 
In the mid-1990s, however, these attempts to establish the links between neighbourhoods and the larger city-region were disrupted with the initiation of a new programme, the Pacte de relance pour la ville (PRV, hereafter) of 1996, introduced by the right-wing Juppé government. The main idea behind this measure was to foster economic activity and to increase employment through tax concessions and public subsidies in designated areas. ${ }^{4}$ For the most part, the PRV retained areas that were already included under DSQ or City Contracts programs. The novelty of the programme was what it did with the included areas. A formula called "Synthetic Index of Exclusion" (ISE) was devised to assign neighbourhoods to their proper places on a scale of exclusion. The attempt, in the early 1990s, was to measure the gap between the neighbourhoods and their surrounding areas through a calculation of concentration. The designated neighbourhoods were seen as "neighbourhoods at risk", and the attempt was to discern symptoms of larger programmes and populations at risk (Estèbe 2001). This time, however, the attempt was to measure how badly these neighbourhoods were "excluded". The PRV created a hierarchical geography of priority neighbourhoods, all of which were seen as "excluded", although some more excluded than the others. This was a shift from a relative geography of difficulties to an absolute geography of exclusion (or "threat"), determined by centrally decided upon criteria, transforming the geography of the priority neighbourhoods of urban policy into a "statist (étatique) geography".

The PRV was arguably the closest French urban policy got to a neoliberal approach, with a shift in focus from solidarity between communes to economic success within strictly defined spaces of intervention. It was conceived almost exclusively in economic terms and with an exclusive focus on delimited neighbourhoods as neatly defined, exclusive, and calculable spaces of intervention. This spatial approach meant a farewell to redistributive policies conceived to foster collaboration between communes within the larger city-region. With the propositions following from this particular spatial conceptualization, solidarity between communes in terms of finance and the provision of social housing, which was an important feature, if unrealized, of the LOV of 1991, had disappeared. For the PRV, the neighbourhoods existed in and of themselves, as neatly delimited areas that supposedly contained both the problem and its solution. The inhabitants and local specificities, in the process, turned into internally homogeneous spatial categories, and the earlier ideas about appropriation of lived spaces by inhabitants themselves disappeared. The Jospin government tried to restore the contract system, and to re-encourage solidarity between communes in terms of finance and the provision of social housing by a law that was passed 
in December 2000 (Loi relative à la Solidarité et au Renouvellement urbain, SRU). Shortly after the passing of this law, however, a rightwing government took office following the 2002 elections, and went back to the statist geography of the PRV with the creation of 41 additional sites to benefit from tax concessions.

\section{From Working-class Neighbourhoods to Ghettos}

Many scholars working on contemporary France have observed a change in the "attitude" of the republic towards its "strangers". This change consisted of a renewed enthusiasm, particularly in the 1990s, for the republican tradition with nationalistic overtones-to which I refer to as republican nationalism-and has been most notably felt, it has been argued, in citizenship and immigration policies (Balibar 2001; Blatt 1997; Feldblum 1999; Tévanian and Tissot 1998). French urban policy, just like citizenship and immigration policies, has been affected by this burgeoning republican nationalism in the 1990s with an emphasis on the "values of the republic" that were seen to be threatened by communitarian groupings and the formation of ghettos in the peripheral areas of cities. This change was most remarkable in the discursive (re-)articulations of intervention areas under urban policy. Whereas in the UK and US neoliberal forms of urban governance have mobilized the idea of "community", French urban policy tried to avoid precisely that. Instead of encouraging the formation of communities endowed with opportunities on the condition of assuming wider responsibilities ("partnership") that were previously in the domain of the state (Raco and Imrie 2000), French urban policy emphasized the duties of the state, and conceived partnership in statist terms as collaboration between different departments of the government (see Hall and Hickman 2002). In this sense, it was not informed by neoliberalism's emphasis on economic efficiency and competitiveness, but by republicanism's insistence on a common culture and identity, fragmentation of which was seen as a threat to the integrity of the republic.

In the first years of the DSQ program, there was a concern with the disproportionately negative effects of the economic crisis on social housing neighbourhoods at the peripheral areas of large cities. Such neighbourhoods were hard hit by the loss of many industrial and manufacturing jobs, and a xenophobic discourse towards immigrants had started to develop partly because of increasing economic insecurity. The conceivers of the DSQ insisted that social housing neighbourhoods be seen as "working class" or "popular neighbourhoods", thus linking the problems in such neighbourhoods to larger economic dynamics, and their inhabitants to a common political culture: 
The institutions must accept the reality of these neighbourhoods as popular neighbourhoods. Places of conflict, but also of solidarity, places of material poverty, but also of proliferation of popular cultures, places of difference, but also of blending, places of reject, but also of social insertion. (Dubedout Report 1983:57)

But starting with the 1990s, the problems of social housing neighbourhoods and banlieues were increasingly couched in cultural and "ethnic" terms, as threats to "the republic". Influential in this was another series of riots in the early 1990s, and the specific context in which they occurred. The international scene was occupied with Intifada (already in place for three years), the Rushdie affair of 1988, and the Gulf War (to start in January 1991). The early 1990s were also particular in that the continent was no longer divided neatly to distinguish the same from the other, friend from enemy, following the demise of the Berlin Wall in 1989, urging the French state, already preoccupied with "menaces to the French identity" and Europeanization, to affirm its authority and sovereignty in the midst of political restructuring that modified seemingly immutable political spaces. In addition to these, the Los Angeles riots occurred in 1992. In France, there was a hot debate following the Islamic headscarf affair of 1989. ${ }^{5}$ The reflection of these events in France was a resurgence of debates around, and arguments against, immigrants and the formation of particular communities, focusing particularly on North African immigrants and Islam (see Cesari (1997) for a more detailed account of the "fear of Islam"). From then on, the social housing neighbourhoods in the banlieues would also be associated, explicitly or not, with "Islamic fundamentalism". This new discursive articulation, again, may be accounted for by the particular international context of the early 1990s, because when Islam had first "appeared" in certain banlieues, as Battegay and Boubeker (1991-1992:58) argue, it was seen as a "good thing" by the administrators, who thought that it would calm down the young people a bit.

In the 1990s, perils of "communitarianism" and the problem of "ghettos" became integral parts of the urban policy discourse. "Ethnic co-existence" in the neighbourhoods, it was believed, posed a threat to the secular principles of the republic and to its values (Geindre 1993). Communitarianism is basically used to refer to ethnic communities, formation of which is seen in sharp contradiction with the republican principles. Ghettos are the spatially reified forms of this ethnic nightmare haunting the republic, even though the areas referred to as ghettos in France are neither ethnically homogeneous, nor large enough to function as self-contained areas apart from the city (de Rudder 1992; Hargreaves 1995; Wacquant 1999a). The term, however, has been associated to the neighbourhoods of urban policy 
in the banlieues, informing even a 1991 law known as the LOV (loi d'orientation pour la ville), and also as the "anti-ghetto law", which was aimed at fighting against segregation in the designated neighbourhoods of urban policy. In this new articulation, the dystopian images of the North American city have been very influential in shaping the discourse on banlieues in France (Wacquant 1999a). These dystopian images of the city were also accompanied by what Wacquant (1999b) calls "the punitive wind" blowing from the other side of the Atlantic. The wind brought two things at once: a bad example to be avoided and a good one to be imitated. The bad example consisted of the wrong-headed approach towards "communities"-the so-called "Anglo-Saxon model", unacceptable under the republic-and dystopian images of the city with ghettos. The good one, on the other hand, consisted of repressive measures, marking a remarkable shift from a social to a penal logic, and making unprecedented security measures possible.

\section{From the Right to the City to Right to Security}

Urban policy was originally conceived by the mayor of Grenoble, Hubert Dubedout, who was one of the founders of municipal action groups (Groupes d'action municipale) in the 1970s, which sought to promote the idea of self-management (autogestion) at the urban level. The DSQ programme in the early 1980s put great emphasis on creating a local political dynamic, with such strong political ideals as the "democratization of the management of the city", "appropriation of space by inhabitants", and "the right to the city". Such ideals found little or no realization under the strong presence of the state and changing approaches to urban policy. Nevertheless, there was, at the start, a strong political will with an aim to generate new ways of thinking about the city, grounded in the spaces of intervention themselves. In the 1980s, social development of neighbourhoods was above all the work of militants working in the neighbourhoods (Donzelot and Estèbe 1999). Although it was "put on the back burner" (Le Galès 1995:267) during Jacques Chirac's term as Prime Minister in the "cohabitation" government with the Socialists (1986-1988), urban policy became a central issue again with the change of government. President François Mitterrand declared that the city would be one of his priorities during his second term (1988-1995). The strong political will, therefore, remained, but there was a change in approach, from a more militantist one to a more proceduralist and technocratic one-more in line with the tradition of policy-making by what Schmidt (2001:238) calls a "governmental-technocratic elite". With the institutional reforms of 1988, the National Council of Cities (CNV), an inter-ministerial committee (CIV), and the Délégation 
interministérielle à la ville (DIV) were created. Thus, urban policy was given administrative status within the state apparatus, "symbolizing the commitment of the state to tackling the urban crisis" (Le Galès and Mawson 1994:27). This was followed by the creation of a City Ministry in 1990, and the passing of new laws in the French state's attempt to "fight against exclusion" and to "prevent ghettoization" of certain neighbourhoods. The effort was so intense that the early 1990 s, as far as urban policy goes, is usually referred to as "the return of the state" (Barthélémy 1995; Merlin 1998).

The "return of the state", however, involved more than the return of the social state; it also gave the first signs of the coming of the penal state, starting with the engagement of the repressive machinery of the state with the "urban question". The first one was the Ministry of Justice, which started to collaborate with the new City Ministry. There was a concern with the weakening of the authority of the law in the city, and the proposal made was to have a "more direct presence of the Law [la Justice] in sensitive neighbourhoods" (a new term entering the agenda in the early 1990s), with the creation, for example, of Maisons de Justice et du droit (literally "Houses of Justice and Law", MJD, hereafter). The MJDs were conceived to "reinforce the presence of the Law" (Ministère de la Justice 1991:4, 5) through a rapid, on the spot, treatment of delinquency in "sensitive neighbourhoods". Another state institution that turned to urban issues in the early 1990s was the French Intelligence Service (Renseignements Généraux, RG hereafter). It was decided that the RG would keep certain neighbourhoods under surveillance, and it was the list of the neighbourhoods of urban policy that was directly taken as a starting point (Bui-Trong 2000). To this end, a special section called "urban violence"-another new term entering the agenda in the early 1990s-was created at the RG in 1990, which then changed its name to "Cities and banlieues". Since then, banlieues are under surveillance with a stated aim to fight against "urban violence".

A more authoritarian and repressive approach became increasingly prominent in the 1990s, under governments both of the right and the left, which also changed the legitimation of state intervention. The arrival of a right-wing government in 1993 marked a major point in this change. The first parliamentary debate of the new government was devoted to the "malaise of banlieues". Prime Minister Balladur argued that "the spirit of the Republic" and "the authority of the State" were "challenged". The three priorities envisaged by his party, RPR, were "authority, activity, and identity". "Authority" meant the return of the (penal) state; "activity" referred to tax benefits for firms; and "identity" meant integration by "re-giving the taste of being French to those that become so by chance" (Le Figaro 28 April 1993:6). Linking the banlieues with issues such as "the spirit of the 
Republic", "the authority of the State", and "French identity" was something virtually missing from the former governments' discourse in the 1980s. Whereas earlier policies were more concerned with alleviating inequalities rising from the economic crisis through comprehensive approaches, the new government proposed a shift in the legitimation of state intervention. The banlieues evoked an image of menace, and no longer a space where one could identify the signs or symptoms of larger problems. The problem started to change direction from the neighbourhoods themselves to the republic, with a shift in emphasis from prevention to repression through a legitimizing discourse organized around the issue of "insecurity". Thus, when the Left came back to power in 1997, Prime Minister Jospin made "right to security" a priority issue after unemployment. The Jospin government created a new institution, the Conseil de sécurité intérieure (Interior Security Council), and before even appointing a minister for the City, it initiated two new measures: the police de proximite (proximity police) to be deployed mainly in the so-called sensitive neighbourhoods, and the Contrats locaux de sécurité (Local Security Contracts, CLS hereafter) targeted, again, mainly at the sensitive neighbourhoods. ${ }^{6}$ The CLS were signed with the central state, and allowed municipalities to devise and implement security measures. By June 2001, 527 CLS, of which $60 \%$ were in the intervention areas of urban policy, were already signed, and another 209 were under elaboration (Cour des Comptes 2002). In 2002, there were 91 working MJDs, and 38 more were expected to be constructed by the end of the year. A total of 219 districts were planned to have police de proximité, with the priority given to the neighbourhoods of urban policy where one-quarter of the active population, more than one-third of the young population and foreigners were unemployed in 1999.

\section{Conclusions}

Although the French state is committed to some form of moderate neoliberalism in its contemporary restructurings, the effects of this commitment on urban policy have been only partial. Despite brief periods of experimentation with neoliberal ideas, French urban policy has not sought to institutionalize inter-urban competition and to encourage a growth-first competitive logic as an overriding goal. Economic growth and competition have not replaced social issues as primary objectives; urban policy is a social, not an economic development, policy. In this sense, it has followed the political rationality of the republican tradition, and not that of neoliberalism, which seeks to extend and disseminate market values.

The transformations of urban policy reflect the restructuring of the French state along more authoritarian lines and its growing 
preoccupation with the presence of "other"-mainly non-Europeancultures. In the 1980s, there was still-and this is the major difference between the 1980s and the 1990s - a search for the causes (mostly of an economic order since the economic crisis of the early 1970s was still a relatively recent issue) of perceived problems, including discrimination and racism. The banlieues were not articulated as threats in and of themselves, and the concern was more with the problems facing the inhabitants than with "menaces to the republic". There was not a single reference to "the republic" in the 1980s in urban policy discourse. Only in the 1990s the republic became an integral part of urban policy, shifting attention from structural dynamics to menaces to French identity, and emphasizing a much more authoritarian role for the state. Starting with the 1990s, a spatial order of inside and outside was largely consolidated following the republican turn, hitting the ground with concrete security measures directed towards the banlieues. The search for the causes of perceived problems gradually disappeared, and the banlieues came to be seen as problems in and of themselves. The focus shifted from prevention to repression, and the discursive articulation of the banlieues as such as a problem made repressive measures not only possible, but legitimate, even "inevitable" as well. This is despite the fact that the list of urban policymakers has basically remained "unchanged"; that is, new neighbourhoods are constantly added to the list while the older ones remain. For example, the very 16 neighbourhoods that were selected in 1982 as "neighbourhoods in difficulty" are still on the list, two decades later, as "sensitive neighbourhoods". The same is true for about 500 neighbourhoods included since 1989; they have practically all remained on the list since then, although the neighbourhoods with a "bad reputation" in the 1980s are now discursively constituted as "menace" (Estèbe 2004), shifting from being neighbourhoods "in danger" to "dangerous neighbourhoods" (Bonelli 2001).

Thus, while urban policy has not become a means for producing competitive spaces, it has become more and more concerned with containing certain spaces and populations seen to be problematic. For the Socialists of the early 1980s, urban policy had a more political connotation, as part of their discourse organized around such themes as "a new urban civilization" and "new citizenship". The Chirac government of 1986-1988 - which came to power with an explicit neoliberal agenda-saw urban policy as a means for addressing the issue of immigration, and countering the rise in the popularity of the Extreme Right in the banlieues (Damamme and Jobert 1995; Collovald 2001). Urban policy had a central place in the Rocard government's "fight against exclusion" in the late 1980s and early 1990s. The two successive right-wing governments used urban policy to create competitive territories, to advance arguments with 
nationalist overtones, and to deploy the repressive machinery of the state. The Jospin government, finally, tried to open up the spatial focus of urban policy by restoring the City Contracts program, although its most concrete applications consisted of the deployment of the penal state in the designated neighbourhoods.

Two implications of the French case seem to me to be important points with which to conclude. The first is that accounts of neoliberalization should be sensitive to established political traditions for they affect processes of neoliberalization and state restructuring. This implies giving due attention to different political rationalities guiding policy-making, inherited institutional structures and practices, and the role of dominant political traditions in shaping both state actions and public response to them. The second relates to the issue of the penal state. An integral part in the consolidation of the penal state in France has been the state's practices that produce spaces. Urban policy and its spaces of intervention have become the major sites upon and through which the penal state has been disseminated. The disciplinary practices of the penal state, then, are substantially spatial practices that produce spaces of intervention (or containment), although the discursive articulations of such spaces and the modes of legitimization vary depending on established political traditions, as do forms of neoliberalization and state restructuring.

\section{Acknowledgements}

I am grateful to Claire Hancock, Walter Nicholls, Jamie Peck, and three anonymous referees of Antipode for very helpful comments and suggestions. All responsibility, it goes without saying, remains mine.

\section{Endnotes}

${ }^{1}$ Pasqua was the Minister of the Interior in the Chirac government of 1986-1988 as well, and had earned a reputation for his repressive measures.

${ }^{2}$ As Bachmann and Le Guennec (1996:353-354) argue, the reception of what happened in several cities of Britain in the French media was conditioned by the "particularity" of the French republic. "Race riots" were possible in Britain, but not in the "one and indivisible" French republic. This connects to the republican tradition and its emphasis on a common culture and identity briefly discussed in the section above.

3 "(French) urban policy", hereafter, refers to this particular policy that was initiated in the early 1980 s by the Socialist government.

${ }^{4}$ The idea was already there in 1991 with the LOV (although it was never widely applied), giving local collectivities the possibility of tax concessions for the creation and extension of business. The Pacte de relance involved public subsidies as well, and extended the measure to include already existing firms.

${ }^{5}$ The same year, Prime Minister Michel Rocard created the Haut Conseil à l'Intégration (High Council for Integration). It should be remembered that the headscarf was also a strong symbol of resistance to the colonial rule. 
${ }^{6}$ This new measure turned designated neighborhoods into profitable areas for private security firms-the "security merchants", as a recent documentary named them. Thus formed a relatively new sector that employs more than 100,000 people, a sector that hires and advances more rapidly than the rest of the economy in recent years: the private security sector, or the "security merchants". Since then, the banlieues have become "the new El Dorado" for private companies offering security services, such as the preparation of "local security diagnostics" (which is required to have a local security contract), creation of municipal police, and installation of surveillance cameras (Marchands de sécurité 2002).

\section{References}

Bachmann C and Le Guennec N (1996) Violences urbaines. Ascension et chute des classes moyennes à travers cinquante ans de politique de la ville. Paris: Albin Michel

Balibar E (2001) Nous, citoyens d'Europe? Les frontières, l'Etat, le people. Paris: La Découverte

Barthélémy A (1995) Un avenir pour la ville. Face à la crise urbaine. Paris: Esprit

Battegay A and Boubeker A (1991-1992) Des Minguettes à Vaulx-en-Velin: Fractures sociales et discours publics. Les Temps modernes 545-546:51-76

Blatt D (1997) Immigrant politics in a republican nation. In A G Hargreaves and M McKinney (eds) Post-Colonial Cultures in France (pp 40-55). London: Routledge

Bonelli L (2001) Des quartiers en danger aux "quartiers dangereux". Le Monde diplomatique February:18-19

Brenner N and Theodore N (2002) Cities and the geographies of "actually existing neoliberalism". Antipode 34(3):349-379

Brown W (2003) Neo-liberalism and the end of liberal democracy. Theory \& Event 7(1). http://www.muse.jhu.edu/journals/theory_and_event/v007/7.lbrown.html (last accessed 23 March 2005)

Budgen S (2002) The French fiasco. New Left Review 17(September):31-50

Bui-Trong L (2000) Violence urbaine dans les quartiers sensibles. In M-F Mattei and D Pumain (eds) Données Urbaines 3 (pp 123-136). Paris: Anthropos

Cesari J (1997) Faut-il avoir peur de l'Islam? Paris: Presses de Sciences Po

Chaline C ([1997] 1998) Les politiques de la ville. 2nd ed. Paris: Presses Universitaires de France

Collovald A (2001) Des désordres sociaux à la violence urbaine. Actes de la recherche en sciences sociales 136-137(March):104-113

Cour des Comptes (2002) La politique de la ville. Rapport public particulier. Paris: Les éditions des Journaux Officiels

Damamme D and Jobert B (1995) La politique de la ville ou l'injonction contradictoire en politique. Revue française de science politique 45(1):3-30

de Rudder V (1992) Immigrant housing and integration in French cities. In D L Horowitz and G Noiriel (eds) Immigrants in Two Democracies: French and American Experience (pp 247-267). New York: New York University Press

Donzelot J and Estèbe P (1999) Réévaluer la politique de la ville. In R Balme, A Faure and A Mabileau (eds) Les nouvelles politiques locales: dynamiques de l'action publique (pp 321-344). Paris: Presses de Sciences Po

Dubedout H (1983) Ensemble, refaire la ville. Rapport au Premier ministre du Président de la Commission nationale pour le développement social des quartiers. Paris: La Documentation française

Estèbe P (2001) Instruments et fondements de la géographie prioritaire de la politique de la ville (1982-1996). Revue française des affaires sociales 3:25-38

Estèbe P (2004) L'usage des quartiers. Action publique et géographie dans la politique de la ville (1982-1999). Paris: L'Harmattan 
Feldblum M (1994) Commentary: reconsidering the "republican" model. In W A Cornelius T Tsuda, P L Martin and J F Hollifield (eds) Controlling Immigration: A Global Perspective (pp 177-179). Stanford: Stanford University Press

Feldblum M (1999) Reconstructing Citizenship: The Politics of Nationality Reform and Immigration in Contemporary France. New York: State University of New York Press Geindre F (1993) Villes, démocratie, solidarité: Le pari d'une politique. Rapport du groupe Villes, Commissariat Général du Plan. Paris: La Documentation française

Hall S and Hickman P (2002) Neighbourhood renewal and urban policy: A comparison of new approaches in England and France. Regional Studies 36(6):691-696

Hargreaves A G (1995) Immigration, "Race" and Ethnicity in Contemporary France. London and New York: Routledge

Hubbard P (2004) Revenge and injustice in the neoliberal city: Uncovering masculinist agendas. Antipode 36(4):665-686

Jazouli A (1992) Les années banlieues. Paris: Seuil

Jennings J (2000) Citizenship, republicanism and multiculturalism in contemporary France. British Journal of Political Science 30(4):575-597

Jobert B and Théret B (1994) France: La consécration républicaine du néolibéralisme. In B Jobert (ed.) Le tournant néo-libéral en Europe. Idées et recettes dans les pratiques gouvernementales ( $\mathrm{pp}$ 21-85). Paris: L'Harmattan

Jones M and Ward K (2002) Excavating the logic of British urban policy: Neoliberalism as the "crisis of crisis-management". Antipode 34(3):473-494

Knapp A and Wright V (2001) The Government and Politics of France. 5th ed. London: Routledge

Larner W (2000) Neo-liberalism: Policy, ideology, governmentality. Studies in Political Economy 63(autumn):5-25

Larner W (2003) Neoliberalism? Environment and Planning D: Society and Space 21:509-512

Le Galès P (1995) Politique de la ville en France et en Grande-Bretagne: volontarisme et ambiguïtés de l'Etat. Sociologie du travail 2:249-275

Le Galès P and Mawson J (1994) Management Innovations in Urban Policy: Lessons from France. London: The Local Government Management Board

Levy J (2001) Partisan politics and welfare adjustment: The case of France. Journal of European Public Policy 8(2):265-285

Levy J (2002) "The state after statism: French economic and social policy in the age of globalization." Paper presented at the Thirteenth International Conference of Europeanists, Chicago, IL, 14-16 March

MacLeod G (2002) From urban entrepreneurialism to a "revanchist city"? On the spatial injustices of Glasgow's renaissance. Antipode 34(3):602-624

Marchands de sécurité (2002) Program transcript, directed by Richard Vargas, produced by Coup d'œil productions

McCarthy J and Prudham S (2004) Neoliberal nature and the nature of neoliberalism. Geoforum 35:275-283

Merlin P (1998) Les banlieues des villes françaises. Paris: La Documentation française

Ministère de la Justice (1991) La justice agit dans la ville (Paris)

Mucchielli L (2001) Violences et insécurité: Fantasmes et réalités dans le débat français. Paris: La Découverte

OECD (1998) Integrating Distressed Urban Areas. Paris: OECD

Peck J (2001) Neoliberalizing states: Thin policies/hard outcomes. Progress in Human Geography 25(3):445-455

Peck J (2003) Geography and public policy: Mapping the penal state. Progress in Human Geography 27(2):222-232

Peck J (2004) Geography and public policy: Constructions of neoliberalism. Progress in Human Geography 28(3):392-405 
Peck J and Tickell A (2002) Neoliberalizing space. Antipode 34(3):380-404

Raco M and Imrie R (2000) Governmentality and rights and responsibilities in urban policy. Environment and Planning $A$ 32(12):2187-2204

Safran W (1990) The French and their national identity: The quest for an elusive substance. French Politics and Society 8(1):56-67

Schmidt V A (2001) Discourse and the legitimation of economic and social policy change in Europe. In S Weber (ed) Globalization and the European Political Economy (pp 229-272). New York: Columbia University Press

Schmidt V A (2002) The Futures of European Capitalism. Oxford: Oxford University Press

Schmidt V A (2003) French capitalism transformed, yet still a third variety of capitalism. Economy and Society 32(4):526-554

Silver H (1993) National conceptions of the new urban poverty: Social structural change in Britain, France and the United States. International Journal of Urban and Regional Research 17(3):336-354

Silver H (1994) Social exclusion and social solidarity: Three paradigms. International Labour Review 133(5-6):531-578

Tévanian $\mathrm{P}$ and Tissot S (1998) Mots à maux: Dictionnaire de la lepénisation des esprits Paris: Editions Dagorno

Thrift N (1999) Cities and economic change: Global governance? In J Allen, D Massey and M Pryke (eds) Unsettling Cities (pp 271-308). London: Routledge/ The Open University

Wacquant L (1999a) Urban marginality in the coming millennium. Urban Studies 36(10):1639-1647

Wacquant L (1999b) Ce vent punitif qui vient d'Amérique. Le Monde diplomatique April: 1, 24-25

Wacquant L (2001) The penalization of poverty and the rise of neo-liberalism. European Journal on Criminal Policy and Research 9:401-412 